\title{
Workers' perception of workplace bullying: A cross-cultural study
}

\author{
Jordi Escartín \\ University of Barcelona, Barcelona, Spain \\ Dieter Zapf \\ University of Goethe-Frankfurt am Main, Frankfurt am Main, Germany \\ Carlos Arrieta \\ University of San José, San José, Costa Rica \\ Álvaro Rodríguez-Carballeira \\ University of Barcelona, Barcelona, Spain
}

\begin{abstract}
This study is one of the first studies to approach workplace bullying crossculturally. It sought to compare employees' understanding of workplace bullying in two different world regions: Central America and Southern Europe, regarding three aspects of workplace bullying: psychological vs. physical harassment, hierarchical vs. horizontal bullying, and direct vs. indirect aggression. A convenience sample of 246 workers provided their own definition of workplace bullying through a single, open-ended question. The results showed that employees from Central America emphasized the physical component of workplace bullying more than the Southern European employees. However, similarities in the conceptualization of workplace bullying across both cultures were found as well. Both Southern European and Central American employees defined workplace bullying mainly as a hierarchical phenomenon, where the aggression took the form of direct strategies. Such differences and similarities bring to the field some positive inputs for the development and implementation of different strategies for dealing effectively with this phenomenon.
\end{abstract}

Keywords: Cross-cultural; Emotional abuse; Mobbing; Workplace bullying.

Correspondence should be addressed to Jordi Escartín, Department of Social Psychology, University of Barcelona, Pg. Vall d'Hebrón, 171, 08035 Barcelona, Spain.

E-mail: jordiescartin@ub.edu

(C) 2010 Psychology Press, an imprint of the Taylor \& Francis Group, an Informa business http://www.psypress.com/ejwop

DOI: $10.1080 / 13594320903395652$ 


\section{ESCARTÍN ET AL.}

Research on workplace bullying has joined the interest of scientists who have studied many kinds of abusive behaviour at work under a myriad of terms, such as violence, aggression, abuse, harassment, bullying, mobbing, etc. (Branch, 2008). Despite such a proliferation of terms, some authors have tried to confine them into broad constructs such as workplace aggression (Barling, Dupré, \& Kelloway, 2009) or workplace victimization (Aquino \& Thau, 2009). The scope of the present study is to focus on workplace bullying, mainly characterized by negative acts that occur in a persistent and systematic way (Einarsen, Hoel, Zapf, \& Cooper, 2003).

Current research on workplace bullying demonstrates that this phenomenon not only involves bullies and bullied victims, but may also have a negative impact at an organizational level (Matthiesen \& Einarsen, 2001). Several studies (e.g., Hoel \& Cooper, 2000; Vartia, 2001) suggest that bullying may have a negative effect on witnesses or bystanders. In the study of Hoel and Cooper (2000), more than 30\% of the participants agreed with the statement "bullying reduces our efficiency". Hoel, Sparks, and Cooper (2001) highlighted that such phenomenon can lead to increased pressure on social services and welfare, growing medical costs, premature retirement, or potential loss of productive workers. The negative consequences that bullying may bring to the workplace (Lewis \& Rayner, 2003) have promoted interest in the study of different aspects of the issue, such as the frequency and duration of the workplace bullying behaviours (Leymann, 1996) or the imbalance of power (Harvey, Treadway, Heames \& Duke, 2009; Liefooghe \& Mackenzie-Davey, 2001). However, the question of how the cultural context impacts the individuals' comprehension of workplace bullying has been neglected in most investigations (Anderson \& Bushman, 2002). Several authors have stressed that researchers should examine cultural structures that enable, trigger, and reward bullying, in order to reduce its occurrence (e.g., Hoel \& Salin, 2003; Lutgen-Sandvik, Tracy, \& Alberts, 2007).

This aspect is important since many studies have shown that the prevalence of workplace bullying varies not only according to the workers' perceptions (Ireland, 2006), but consistent with Hofstede's theory (1980) also according to their national culture (Moayed, Daraiseh, Shell, \& Salem, 2006). The overall emerging picture from such studies is that some countries such as those in Southern Europe (e.g., Spain), characterized by a higher power distance and a considerably higher degree of uncertainty avoidance, indicate a high prevalence rate of bullying in international comparisons (Moreno-Jiménez, Rodríguez-Muñoz, Salin, \& Benadero, 2008). Countries in Northern Europe, UK, and Australia, which are characterized by negative attitudes towards signs of abuse of power, low power distance, feminine values, and individualism, tend to have a lower threshold for experiencing inadequate behaviours as bullying and may be more ready to 
use the right to complain about it (Einarsen, 2000). One possible explanation is that the cultural variation in construing the meaning of specific behaviours makes it harder to reveal which behaviours are and are not to be considered abusive. Some forms of interaction in the workplace, traditionally accepted in the past, are perceived today as improper, abusive, and unethical in certain cultural environments. Thus, in order to enhance the understanding of workplace bullying, it becomes relevant and necessary to understand the cultural context (Gelfand, Erez, \& Aycan, 2007). So, clarifying the definition of bullying is important both theoretically and practically, because of the possible underreporting or overreporting of workplace bullying as a result of differing definitions regarding what workplace bullying is. As a result, this may have serious consequences for interventions in organizations (cf. Branch, 2008; Saunders, Huynh, \& Goodman-Delahunty, 2007). In that sense, some studies have stressed how employees may have different conceptualizations of workplace bullying to those of the researchers (Escartín, Rodríguez-Carballeira, Porrúa, \& Martín-Peña, 2008; Escartín, Rodríguez-Carballeira, Zapf, Porrúa, \& Martín-Peña, 2009; Liefooghe \& MacKenzie-Davey, 2003), which has also been pointed out by Smith, Cowie, Olafsson, and Liefooghe (2002, p. 1131): "This imperfect correspondence between popular and scientific definition of terms such as bullying is an issue that the researcher must remain aware of." Therefore, different authors have emphasized the necessity for employing different qualitative research methodologies to explore the meaning of different social phenomena as experienced by individuals themselves (Strandmark \& Hallberg, 2007).

Furthermore, although there are several studies on individual acts of violence within certain cultures, remarkably few cross-cultural studies have been developed (Bond, 2004; Tedeschi \& Bond, 2001; Zapf, Escartín, Einarsen, Hoel, \& Vartia, 2010). One reason for this is the difficulties that these studies bring forth, as noted by Triandis because "cross-cultural research is tricky and difficult" (2004, p. 15). He stated that "to do research that is ignorant of or insensitive to the major features of the local culture often means to do poor research and thus wastes the time of local subjects, as well as the funds, and that is unethical" (Triandis, 1992, p. 232). Peterson and Smith (1997) provided a comprehensive list of cultural determinants, other than country, that should be considered, such as: language, proximity and topography, religion, economic development, technological development, political boundaries, industry type, and climate. These factors may influence meaning and thus the measures of a study. This suggests that with regards to the study and management of bullying at work, the question of whether the knowledge generated in one cultural setting is transferable to different parts of the world has not yet been resolved. It is likely that what works in one culture may not work in another. 


\section{ESCARTÍN ET AL.}

When dealing with workplace bullying it is important to know precisely what employees think constitutes "workplace bullying". Moreover, for a deeper understanding of this phenomenon, it is interesting to know whether it is the same over time and place and across cultures. How might workplace bullying vary cross-culturally? Do people from different cultures experience similar kinds of aggression at work? Is there only one blueprint for workplace bullying? Or is this concept related to the context it is studied in? Although this article will not try to answer all these questions, they have directed the present study. Hence, this study will seek to compare employees' understanding of workplace bullying in two different world regions: Central America (Costa Rica) and Southern Europe (Spain).

\section{CULTURAL SIMILARITIES AND DIFFERENCES BETWEEN COSTA RICA AND SPAIN}

According to House, Hanges, Javidan, Dorfman, and Gupta (2004, p. 15), culture is defined as: "shared motives, values, beliefs, identities, and interpretations or meanings of significant events that result from common experiences of members of collectives and are transmitted across age generations". In relation to cultural issues, Hofstede $(1980,1994)$ ranked national cultures according to four cultural dimensions: power distance, individualism, uncertainty avoidance, and masculinity. He suggested that amongst European countries, four clusters could be identified, one of them being the Southern European countries (Spain, Italy, Portugal, France, and Greece), heavily influenced by Roman culture (Latourette, 1965) and whose main characteristics are high uncertainty avoidance and high power distance. Uncertainty avoidance could be defined as "the extent to which members of an organization or society strive to avoid uncertainty by relying on established social norms, rituals and bureaucratic practices" (House et al., 2004, pp. 11-12), and power distance as "the degree to which members of an organization or society expect and agree that power should be stratified and concentrated at higher levels of an organization or government" (pp. 11-12). In the same way, Central American countries such as Costa Rica, El Salvador, Panamá, and Guatemala were also ranked with similar characteristics to those presented by Southern European countries, namely being high in power distance and high in uncertainty avoidance. In addition to this, the population is predominantly Catholic in both Central American and Southern European nations, which was also related to such cultural dimensions by Hofstede (see Verweij \& Nauta, 1997,

(13) for further information). In that sense, as noted by Rosenn (1998, p. 128), it could also be argued that Central American countries "share a common Roman law heritage, a common Iberian colonial past, and present-day patterns of social organization". 
In our study we chose to compare Spain and Costa Rica because the fact that both countries share the same language (Spanish) facilitated such crosscultural study. Since both world regions show several similarities mostly due to their common heritage, the question could arise whether a comparison of Spain and Central America can, at all, be called cross-cultural. However, according to Transparency International (2008) and the World Economic Forum (2008), significant differences between Costa Rica and Spain exist. In the Corruption Perceptions Index ${ }^{1}$ of Transparency International (2008), Spain is ranked in the 27 th position and Costa Rica in the 53rd, which is a substantial difference (notice that higher ranking means more corruption). In the Global Competitiveness Index Ranking ${ }^{2}$ (2008-2009), Spain is ranked in the 29th position and Costa Rica in the 59th (notice that higher ranking means less competitiveness). In this second report, Spain and Costa Rica are compared according to several features such as basic requirements (institutions, infrastructure, macroeconomic stability, health and primary education), efficiency enhancers (higher education and training, goods market efficiency, labour market efficiency, financial market sophistication, technological readiness, and market size) and innovation and sophistication factors (business sophistication and innovation) (Table 1). Data suggest that Costa Rica systematically receives worse scores than Spain. As an example, with regard to institutions (basic requirements), comparisons about business cost of crime and violence, organized crime, or ethical behaviours of firms, substantial differences exist (i.e., ranking position between Costa Rica and Spain: 108 vs. 59, 73 vs. 53, and 38 vs. 33, respectively).

Azfar and Gurgur (2004) argued that corruption has been shown to increase theft, crime levels, the amount of homicides, and human trafficking. Mayhew and Chappell (2007) pointed out that external workplace violence is more common in some geographical areas than in others, which could bring a "spillover" effect whereby community violence, like street crime or muggings, is extended into vulnerable businesses and their workforce. In sum, there is evidence that crime rates and the presence of gangs are substantially higher in Central America than in Southern Europe, and levels

\footnotetext{
${ }^{1}$ The Corruption Perceptions Index (CPI) is a composite index that ranks countries of the world on a scale from zero (highly corrupt) to 10 (highly clean) presented by Transparency International and can be defined as "the degree to which corruption is perceived to exist among public officials and politicians". According to it, Sweden, Denmark, and New Zealand are perceived to be the world's least corrupt countries, and Somalia, Iraq, Haiti, and Myanmar are perceived to be the most corrupt.

${ }^{2}$ The Global Competitiveness Index (GCI) is published by the World Economic Forum and "assesses the ability of countries to provide high levels of prosperity to their citizens. This in turn depends on how productively a country uses available resources. Therefore, the Global Competitiveness Index measures the set of institutions, policies, and factors that set the sustainable current and medium-term levels of economic prosperity." According to it, the United States tops the overall ranking (1st) and Chad is in the lowest position (131st).
} 


\section{ESCARTÍN ET AL.}

TABLE 1

Ranking positions of Spain and Costa Rica compared across 134 nations

\begin{tabular}{lcc}
\hline & \multicolumn{2}{c}{ Ranking } \\
\cline { 2 - 3 } & Costa Rica* & Spain* $^{*}$ \\
\hline Total population (millions) & 4.5 & 43.6 \\
GCI 2008-2009 & $59^{* *}$ & 29 \\
Basic requirements & 63 & 27 \\
Institutions & 50 & 43 \\
Infrastructure & 94 & 22 \\
Macroeconomic stability & 85 & 30 \\
Health and primary education & 37 & 35 \\
Efficiency enhancers & 60 & 25 \\
Higher education and training & 49 & 30 \\
Goods market efficiency & 49 & 41 \\
Labour market efficiency & 35 & 96 \\
Financial market sophistication & 70 & 36 \\
Technological readiness & 60 & 29 \\
Market size & 78 & 12 \\
Innovation and sophistication factors & 39 & 29 \\
Business sophistication & 42 & 24 \\
Innovation & 38 & 39 \\
\hline
\end{tabular}

Extracted from the Global Competitiveness Report 2008-2009.

$\mathrm{GCI}=$ Global Competitiveness Index.

*Gross Domestic Product (current prices) in millions of US dollars: Spain 1438.95 (rank 8) vs. Costa Rica 26.23 (rank 79).

**Higher values in the ranking means worse competitiveness.

of education are lower (CID Gallup, 2005; Cruz, 2006; PAHO, 1998). Criminal statistics indicate that Central America is one of the most violent (4) regions of the world (ERIC, IDESO, IDIES, \& IUDOP, 2004; Huhn, Oettler, \& Peetz, 2006a, 2006b; Oettler, 2007; Rico, 2006). Moser and McIlwaine (2004, pp. 194-195) in a Latin American context stressed that "violence erodes, transforms and reconstitutes both productive and perverse social capital" and "the gangs, paramilitary or delinquent groups are highly destructive to daily life". This is related not only to recorded and actual crime rates but also to the social perception of crime as noted by Arriagada and Godoy (1990, p. 10), who stated, "sensationalist treatment of violence and delinquent events can generate a climate of fear and a strong feeling of vulnerability in the population, which is not always real, or corresponding to the observed level of violence". In that sense, although physical aggression is not accepted, it has a significant presence in Central American daily life.

814 Moreover, different international reports (PREAL, 2007; UNESCO, 2004) have systematically shown a lack of investment and public spending on 
education in Central America. Similarly, inequity and high levels of dropping out of school have also been a matter of concern.

Taking these findings together we believe that it can be justified to say that a comparison of Spain and Costa Rica represents a comparison of different cultures. As noted by Gelfand et al. (2007) in a recent annual review on cross-cultural organizational behaviour, there is a substantial body of cross-cultural research that has, for example, found similarities and differences between countries with regard to concepts such as commitment, organizational citizenship behaviour, or work autonomy (e.g., Andolsek \& Stebe, 2004; Lam, Hui, \& Law, 1999). However, to date there has been little cross-cultural research on workplace bullying (Zapf et al., 2010). It is, however, not unlikely that significant differences between countries exist according to the way workplace bullying is conceptualized. Therefore, the main question to be addressed in this article is: Are there differences in the way workplace bullying is understood by employees in Central America (i.e., Costa Rica) and Southern Europe (i.e., Spain)?

\section{INTERNATIONAL WORKPLACE BULLYING CONCEPTUALIZATIONS}

There is some scientific evidence that different countries have different conceptualizations of workplace bullying (Di Martino, Hoel, \& Cooper, 2003). In Europe, where the interest in the bullying phenomenon originated, a large number of studies on workplace bullying can be found (Nielsen et al., 2009; Zapf et al., 2010). The European tradition has proposed one of the most accepted definitions of the phenomena to date (Einarsen et al., 2003, p. 15): "Bullying at work means harassing, offending, socially excluding someone or negatively affecting someone's work tasks. In order for the label bullying (or mobbing) to be applied to a particular activity, interaction or process it has to occur repeatedly and regularly (e.g., weekly) and over a period of time (e.g., about six months)." These authors also defined bullying or mobbing as "an escalating process in the course of which the person confronted ends up in an inferior position and becomes the target of systematic negative social acts". As in this case, most definitions of workplace bullying used by researchers include the essential criterion of power imbalance (i.e., Moayed et al., 2006). Hodson, Roscigno, and Lopez (2006) conceptualized power imbalances in relationships in the workplace as potentially occurring in a bidirectional manner between superiors and subordinates, and among peers. Thus, bullying is not limited to vertical aggression from supervisors toward subordinates, as co-workers can derive

power from informal networks or interdependency of job tasks, whereas subordinates' power may derive power from group-based support such as unions (LaVan \& Marty, 2008). 


\section{ESCARTÍN ET AL.}

Keashley and Jagatic (2003) and Lutgen-Sandvik et al. (2007) argued that US researchers have studied a wide variety of negative acts at work, in particular, various minor forms of negative social behaviour such as workplace incivility (Cortina, Magley, Williams, \& Langhout, 2001), social undermining (Duffy, Ganster, \& Pagon, 2002), and also serious physical violence (e.g., Budd, Arvey, \& Lawless, 1996; Kelloway, Barling, \& Hurrell, 2006; Rayner \& Keashly, 2005). In contrast, US studies have given less attention to the phenomenon of bullying as it is conceptualized in many European studies. This is consistent with Yamada (2004), who pointed out that the concept of workplace bullying has very European roots, with the term only becoming more widespread among American employees in the late 1990s. Therefore, according to Rayner and Cooper (2006) in North America, a noncohesive picture has emerged and an acceptance of the concept of bullying has been held back by other competing topics. Davenport, Schwartz, and Elliott (1999) were among the first in the US who adopted the term "mobbing". Keashly (1998) referred to workplace bullying as "emotional abuse", characterized by hostile verbal and nonverbal, nonphysical behaviours directed at a person(s) such that the target's sense of him- or herself as a competent person and worker is negatively affected.

Within Europe there is still a lack of empirical studies in the Southern European countries (Moreno-Jiménez et al., 2008; Topa, Depolo, \& Morales, 2007), despite the high social relevance of workplace bullying in the area (Hirigoyen, 2001). The existing studies adopted the position of Einarsen et al. (2003) and Leymann (1996) and have mainly emphasized the psychological dimension of workplace bullying (e.g., Rodríguez-Carballeira,

(9) Escartín, Visauta, Porrúa, \& Martín-Peña, in press).

Paying specific attention to Central American countries, the major emphasis in such countries is on practical intervention strategies, which is understandable from a sociohistorical approach (Cruz, 2006; Huhn et al., 2006b). Nevertheless, this emphasis on the intervention side of the equation has diminished the efforts on the empirical research side. In addition to this, although sexual harassment has received greater attention (Cortina, 2004), the few studies that have been conducted on workplace bullying are more theoretical (Escartín, Arrieta, \& Rodríguez-Carballeira, 2009) or from a legal or medical perspective (Campos, Abarca, \& Prado, 2005; RomeroPérez, 2006; Salas, 2005), with a considerable lack of empirical research in the field (Pando, Aranda, Franco, \& Torres, 2008).

\section{AIMS OF THE STUDY}

Taking the preceding discussion into account, it is speculated that Central American countries receive a greater influence from North America, 
whereas Southern European countries receive a greater influence from North and Central Europe. Thus, differences in the way workplace bullying is understood by employees in Central America and Southern Europe are expected. Based on the literature reviewed in the previous sections, we will discuss differences between these two world areas with regard to three aspects of workplace bullying: psychological vs. physical harassment, hierarchical vs. horizontal bullying, and direct vs. indirect aggression.

The first aspect to be addressed is whether workplace bullying is perceived to be more physical or more psychological. There are several reasons why we believe that the physical component will be more salient in Central America whereas the psychological component is more salient in Southern Europe. First, we assume that Central America is more influenced by the US, whereas Southern Europe is more influenced by Central and North European concepts. As discussed earlier, there are several competing concepts of bullying in the US and the physical aspects are historically more prominent than the psychological or emotional aspects (i.e., Keashly \& Jagatic, 2003; Kelloway et al., 2006; Lutgen-Sandvik et al., 2007). In particular, cases of severe physical violence found more attention in the public media compared to Europe. In Europe an occupational health perspective distinguishing between bullying and physical violence has been adopted, and is thus present in European research studies. Literature on workplace bullying in Europe has not found the physical component to be significant (Zapf \& Einarsen, 2005). Moreover, in Europe (psychological) bullying received more public attention than physical violence.

Second, as already outlined, Central American societies are much more exposed to physical violence than Spain. Ubiquitous violence may lower the threshold to use physical violence even in the workplace. Therefore, physical violence may be a more prevalent feature of harassment in the workplace and may thus influence workers' understanding of workplace bullying as being physical in nature. Moreover, in a developing country, "simple" and easy to recognize acts such as physical aggression could be more important, above all when crime and violence rates are considered (Cruz, 2006; Huhn et al., 2006a). Therefore, it could be speculated that the physical component of workplace bullying is more significant for the Central American employees than for the Southern European ones (Hypothesis 1a), whereas the psychological dimension would be considered as more significant by Southern European employees as compared to Central American employees (Hypothesis 1b).

The second aspect to be addressed is whether workplace bullying is perceived as a hierarchical or a horizontal phenomenon. The Northern and Central European tradition initiated by Leymann $(1990,1996)$ emphasized the perspective of the victim, conceptualizing workplace bullying as a process occurring between supervisors, colleagues, and subordinates, 
including top-down, horizontal, and bottom-up bullying (Zapf \& Einarsen, 2005). In contrast, the English tradition has focused more on the perpetrator's behaviour (i.e., the bully) and has mainly understood and conceptualized workplace bullying as directed from a supervisor or manager to a subordinate (Adams, 1992), emphasizing a downward process (Hoel \& Beale, 2006). This may have to do with semantic aspects. The term "bullying" is used in the Commonwealth countries (e.g., Great Britain, or Australia). The Webster's New Encyclopedic Dictionary (1995) defines a bully as someone "whose claims to strengths and courage are based on the intimidation of those who are weaker". This has typically been associated with a supervisor who is more powerful because of his or her formal position. Moreover, bullying is often associated with a one-to-one situation. In contrast, in Northern and Central Europe, many countries use the term "mobbing", which was introduced by Leymann. According to Webster's dictionary, a mob is "a large disorderly crowd often tending to violent or destructive action". The term is used in ethology and describes how a crowd of weaker animals (e.g., geese) cast out a stronger animal (e.g., the fox). Given this context, this term tends to emphasize horizontal aggression by a group.

Among researchers, several authors have stressed that American perspectives of bullying imply different concepts compared with the

(10) European tradition (i.e., Saam, in press), whereas others have stated that the terms workplace bullying, mobbing, employee emotional abuse, and nonsexual generalized harassment are synonymous (i.e., Lutgen-Sandvik, 2008). In particular, Einarsen et al. (2003) pointed out that although the concept of bullying as used in English-speaking countries and the term mobbing as used in many other European countries may have some semantic differences and connotations, for all intents and purposes they refer to the same phenomenon. Although from a scientific perspective, we agree with these authors that "bullying" and "mobbing" should be used as synonyms, we believe that in practice the semantic differences of both terms have an effect. In particular, the different connotations of the terms bullying and mobbing may contribute to a different emphasis of vertical versus horizontal aggression.

To sum up, it is expected that the English tradition has a greater influence in the way Central American employees understand workplace bullying. Thus, in Central America it would be more likely understood as supervisor bullying (Hypothesis 2a) which is a top-down process, whereas in Southern European countries it would be more likely perceived as a horizontal process among colleagues, but also as a top-down as well as a bottom-up process. Thus, in contrast to Central America, in Southern European countries bullying will be understood more often as a horizontal as well as a bottomup process (Hypothesis 2b). 
The third and final aspect to be addressed in this article is whether workplace bullying is based mainly on direct vs. indirect aggressive behaviours. Baron and Neuman (1996) applied Buss' (1961) conceptualization of human aggression to hostile workplace behaviours along three dimensions and differentiated between direct and indirect, physical and verbal, and active and passive behaviours. Using this framework, Rodriguez-Carballeira et al. (2005; for further discussion see RodriguezCarballeira et al., in press) proposed six dimensions of workplace bullying. These dimensions were differentiated with regard to emphasizing either direct aggressive acts (directly causing harm to the victim) or indirect aggressive acts (harm caused through the actions of other agents or through assaults on persons or objects valued by the victim). With regard to direct aggressive acts, three categories were differentiated according to their emphasis on emotion ("emotional abuse", such as yelling or threats), cognition ("professional discredit or humiliation", such as belittling knowledge or performance), and behaviour ("devaluation of professional role", that is, undervaluing the role or unjustifiably relieving responsibilities). Three categories of indirect aggressive acts were also differentiated ("isolation" such as physically separating or impeding communication; "control and manipulation of information" such as delaying or not passing on information; and "control-abuse of working conditions", such as intervening or acting negligently in the work environment).

For the different types of harassment, different bases of power may play a role (Keashly, 1998). The indirect negative acts that are very difficult to identify, analyse, and harder to complain about should be more prominent in bottom-up and colleagues' bullying. In contrast, overt offensive or abusive behaviours should be more prominent in supervisor bullying (Kelloway et al., 2006). That would be coherent with the effect-danger ratio theory of aggression (Bjorkqvist, Osterman, \& Hjelt-Back, 1994), because indirect strategies carry a lower risk of being discovered in comparison to tangible behaviours. Therefore, it is expected that the direct aggressive behaviours of workplace bullying would be more significant in the understanding of the phenomenon for the Central American employees than for the Southern European employees (Hypothesis 3a). Furthermore, it is also expected that the Southern European employees would emphasize more the indirect aggressive behaviours than the Central American employees (Hypothesis 3b).

To summarize, the following three sets of research hypotheses will be investigated, corresponding to the three aspects of workplace bullying discussed previously:

Hypothesis 1a: The physical component of workplace bullying will be more significant in the understanding of the phenomenon by the 
Central American employees than for the Southern European employees.

Hypothesis 1b: The psychological component of workplace bullying will be more significant in the understanding of the phenomenon by the Southern European employees than for the Central American employees.

Hypothesis 2a: The hierarchical (top-down) component of workplace bullying will be more significant in the understanding of the phenomenon by the Central American employees than for the Southern European employees.

Hypothesis 2b: The hierarchical (top-down and bottom-up) and horizontal components of workplace bullying together will be more significant in the understanding of the phenomenon by the Southern European employees than for the Central American employees.

Hypothesis 3a: The direct strategies of workplace bullying will be more significant in the understanding of the phenomenon by the Central American employees than for the Southern European employees.

Hypothesis 3b: The indirect strategies of workplace bullying will be more significant in the understanding of the phenomenon by the Southern European employees than for the Central American employees.

\section{METHOD}

\section{Participants}

In the present study, 246 employees, 120 from Costa Rica and 126 from Spain participated. The participation of all employees was completely voluntary and their anonymity was assured (Table 2). Both subsamples were further divided according to the way in which the participants were recruited. Some employees were recruited following a workshop held by the authors on "Prevention of Workplace Bullying" (referred to as "course participants"). The courses were conducted in both world regions and employees attended on a voluntary basis (58 workers of the Health Sector in Costa Rica and 51 of the Education Sector in Spain). The remaining 137 participants were recruited from administrative services (referred to as "service participants") in both countries (62 employees from Costa Rica and 75 from Spain).

The average age in the sample was $35.20(S D=10.06), 154$ workers were female and 92 were male, $55.7 \%$ of the sample worked in the private sector, and $44.3 \%$ in the public sector. Approximately $60 \%$ of the sample had 
TABLE 2

Characteristics of the sample

\begin{tabular}{|c|c|c|c|c|}
\hline \multirow[b]{2}{*}{ Variables } & \multicolumn{2}{|c|}{$\begin{array}{c}\text { Costa Rica } \\
(n=120)\end{array}$} & \multicolumn{2}{|c|}{ Spain $(n=126)$} \\
\hline & $N$ & $\%$ & $N$ & $\%$ \\
\hline \multicolumn{5}{|l|}{ Participant groups } \\
\hline Course participants & 58 & 48 & 51 & 40 \\
\hline Service participants & 62 & 52 & 75 & 60 \\
\hline \multicolumn{5}{|l|}{ Gender } \\
\hline Male & 40 & 33 & 52 & 41 \\
\hline Female & 80 & 67 & 74 & 59 \\
\hline \multicolumn{5}{|l|}{ Age } \\
\hline 30 or under & 56 & 47 & 45 & 36 \\
\hline Over 30 & 64 & 53 & 81 & 64 \\
\hline \multicolumn{5}{|l|}{ Educational level } \\
\hline Elementary & 2 & 1 & 2 & 1 \\
\hline Secondary & 29 & 24 & 11 & 9 \\
\hline Higher education & 89 & 75 & 113 & 90 \\
\hline \multicolumn{5}{|l|}{ Socioeconomic level } \\
\hline Low & 33 & 27 & 15 & 12 \\
\hline Medium & 67 & 56 & 92 & 73 \\
\hline High & 20 & 17 & 19 & 15 \\
\hline \multicolumn{5}{|l|}{ Professional category } \\
\hline Manager or director & 15 & 12 & 7 & 6 \\
\hline Middle management & 19 & 16 & 17 & 13 \\
\hline Baseline employee & 86 & 72 & 102 & 81 \\
\hline \multicolumn{5}{|l|}{ Type of contract } \\
\hline Permanent & 73 & 61 & 75 & 60 \\
\hline Temporary & 47 & 39 & 51 & 40 \\
\hline \multicolumn{5}{|l|}{ Tenure in job position } \\
\hline 6 years or less & 63 & 52 & 53 & 42 \\
\hline More than 6 years & 57 & 48 & 73 & 58 \\
\hline \multicolumn{5}{|l|}{ Activity branch } \\
\hline Education & - & - & 51 & 40 \\
\hline Administration & 62 & 52 & 75 & 60 \\
\hline Health & 58 & 48 & - & - \\
\hline \multicolumn{5}{|l|}{ Sector } \\
\hline Public & 58 & 48 & 51 & 40 \\
\hline Private & 62 & 52 & 75 & 60 \\
\hline
\end{tabular}

ducational level

Elementary

Secondary

Socioeconomic level

\section{Low \\ Medium}

Professional category

Manager or director

Middle management

ine employee

Type of contract

Permanent

6 years or less

Total sample $N=246$ workers.

permanent contracts, whereas $40 \%$ were employed on temporary contracts. In accordance with suggestions of several studies (e.g., Schaffter \& Riordan, 2003; Tsui, Nifadkar, \& Yi, 2007), the equivalence between samples was 


\section{ESCARTÍN ET AL.}

assessed using the Mann-Whitney $U$ statistic, as normal distribution was not assumed. This nonparametric test brings all scores in a rank order and tests for chances of obtaining greater observations in one sample versus the other. If sample size $N>20$, the test statistic $U$ is normally distributed and $z$ can be used instead. No significant differences between samples were found, except for the level of education: $90 \%$ of the Spanish employees had higher education, and $75 \%$ of the Costa Rican employees had secondary education, $z=-3.11, p<.01$.

\section{Instruments}

A questionnaire consisting of two sections was utilized. The first section measured sociodemographic and professional variables such as those given in Table 2. The second section asked workers to give their own definitions of workplace bullying through a single open-ended question: "Think about mobbing for a minute: What is mobbing in your opinion? (You can use examples, for instance)". The question was presented in Spanish and the term "mobbing" was used as this is the expression used in both countries. An open-ended question was used as the authors assumed that, within a culture, words are the medium through which reality construction takes place (Newman, 2008), with language evolving to reflect a phenomenon.

\section{Procedure}

The authors conducted a series of workplace bullying prevention courses between November 2006 and May 2007, focusing on occupational groups identified as having a particularly stressful job (Dollard et al., 2006). The courses were conducted in Costa Rica (within the health sector) and in Spain (within the educational sector). As an initial evaluation before starting the workshop, participants were asked if they would be interested in taking part in a survey about workplace bullying. To prevent researcher bias and/or influence it was agreed that only the word "mobbing" would be used throughout the entire process and no indication of what should be understood by the term was given to the participants. This was to ensure that researchers did not impose an interpretation framework, which might affect the participants' own perceptions of workplace bullying. To approach those employees who did not attend any of the courses (the service participants), the questionnaire was sent via e-mail to different public administrators requesting their voluntary collaboration and assuring them that participants' anonymity would be respected.

All of the 246 definitions of workplace bullying offered by participants were postcategorized by two academic judges according to three criteria 
corresponding to the three sets of research hypotheses (Tables 3 and 4): (1) emphasis on the physical or psychological components (e.g., quotes from participants: "psychological pressure on the worker"; "physical aggression"); (2) emphasis on the direction of the abuse (supervisor, colleagues, or bottom-up bullying) (e.g., quotes from participants: "psychological aggression by a superior"; "work colleagues or bosses make life impossible"; "intense psychological pressure on a colleague, subordinate, or superior"); and (3) emphasis on the direct or indirect workplace bullying behaviours (e.g., quotes from participants: "to insult or humiliate an employee"; "being treated with silence"). In order to investigate the third research question, the Rodriguez-Carballeira et al. (2005, in press) categorization of six components was used. The interrater agreement for all the 246 definitions showed high reliability between scores (Cohen's kappa: .92 for symmetric measures, $p<.01$ ). As the distributions for the variables were different in the samples, nonparametric statistics were used, and the level of significance was set at $p<.05$.

\section{RESULTS}

\section{Physical or psychological components of workplace bullying}

With regard to the type of abuse shown in Table 3, about $80 \%$ of the entire sample described workplace bullying as a psychological phenomenon; the remaining $20 \%$ also included physical aspects in their descriptions. No participant described workplace bullying as an entirely physical phenomenon. As normal distribution was not assumed, the Mann-Whitney $U$ test for the comparison of two independent samples was conducted to determine whether the components highlighted varied by nationality of the different subsamples. The results revealed a significant difference between employees of different nationalities with regard to the emphasis on the physical or psychological component of workplace bullying. The South European employees defined it mainly as a psychological phenomenon, whereas the Central American employees stressed also the physical dimension of such phenomenon, $U=5949.00, z=-4.17, p<.01$.

In both world regions, no significant differences in type of abuse were found between course participants and service participants, as shown in Table 4: Spain, $U=1858.50, z=-0.53, p=.60$; Costa Rica, $U=1745.00$, $z=-0.35, p=.73$.

Hence, in relation to Hypothesis 1a, where it was speculated that the physical component of workplace bullying would be more significant in the Central American employees' definitions than in the Southern European ones, the data supported this hypothesis. Results showed that $30 \%$ of the 
TABLE 3

Characteristics of the study variables for the entire sample, Central America, Southern Europe, service participants, and course participants

\begin{tabular}{|c|c|c|c|c|c|c|c|c|c|c|}
\hline \multirow[b]{2}{*}{ Variable } & \multicolumn{2}{|c|}{$\begin{array}{l}\text { Entire } \\
\text { sample }\end{array}$} & \multicolumn{2}{|c|}{$\begin{array}{l}\text { Central } \\
\text { America }\end{array}$} & \multicolumn{2}{|c|}{$\begin{array}{l}\text { Southern } \\
\text { Europe }\end{array}$} & \multicolumn{2}{|c|}{$\begin{array}{c}\text { Service } \\
\text { participants }\end{array}$} & \multicolumn{2}{|c|}{$\begin{array}{c}\text { Course } \\
\text { participants }\end{array}$} \\
\hline & $N$ & $\%$ & $N$ & $\%$ & $N$ & $\%$ & $N$ & $\%$ & $N$ & $\%$ \\
\hline \multicolumn{11}{|l|}{ Type of abuse } \\
\hline Psychological & 197 & 80.1 & 83 & 69.2 & 114 & 90.5 & 109 & 79.6 & 88 & 80.7 \\
\hline $\begin{array}{l}\text { Psychological and } \\
\text { physical }\end{array}$ & 49 & 19.9 & 37 & 30.8 & 12 & 9.5 & 28 & 20.4 & 21 & 19.3 \\
\hline \multicolumn{11}{|l|}{ Direction } \\
\hline Vertical descendent & 88 & 35.8 & 48 & 40.0 & 40 & 31.7 & 62 & 45.3 & 26 & 23.9 \\
\hline $\begin{array}{l}\text { Vertical descendent }+ \\
\text { horizontal }\end{array}$ & 77 & 31.3 & 39 & 32.5 & 38 & 30.2 & 50 & 36.5 & 27 & 24.8 \\
\hline All directions & 81 & 32.9 & 33 & 27.5 & 48 & 38.1 & 25 & 18.2 & 56 & 51.4 \\
\hline \multicolumn{11}{|l|}{ Emphasis on categories } \\
\hline 1. Isolation & 24 & 9.8 & 10 & 8.3 & 14 & 11.1 & 11 & 8.0 & 13 & 11.9 \\
\hline $\begin{array}{l}\text { 2. Control/manipulation } \\
\text { of information }\end{array}$ & 1 & 0.4 & 0 & 0.0 & 1 & 0.8 & 1 & 0.7 & 0 & 0.0 \\
\hline $\begin{array}{l}\text { 3. Control/abuse of } \\
\text { working conditions }\end{array}$ & 23 & 9.3 & 7 & 5.8 & 16 & 12.7 & 17 & 12.4 & 6 & 5.5 \\
\hline 4. Emotional abuse & 126 & 51.2 & 68 & 56.7 & 58 & 46.0 & 64 & 46.7 & 62 & 56.9 \\
\hline $\begin{array}{l}\text { 5. Professional discredit } \\
\text { or humiliation }\end{array}$ & 31 & 12.6 & 15 & 12.5 & 16 & 12.7 & 17 & 12.4 & 14 & 12.8 \\
\hline $\begin{array}{l}\text { 6. Devaluation of } \\
\text { professional role }\end{array}$ & 41 & 16.7 & 20 & 16.7 & 21 & 16.7 & 27 & 19.7 & 14 & 12.8 \\
\hline
\end{tabular}

definitions applied by the Central American employees stressed the physical component of workplace bullying as well as the psychological one. In comparison, only $10 \%$ of the Southern European employees' definitions did. In relation to Hypothesis $1 \mathrm{~b}$, where it was speculated that the psychological component of workplace bullying would be more significant in the Southern European employees' definitions than in the Central American ones, the data supported this hypothesis as well. Results showed that $90 \%$ of the Southern European employees defined workplace bullying in psychological terms, but only $70 \%$ of the Central American employees did.

\section{Supervisor bullying, colleagues, and bottom-up bullying}

With regard to the direction of the abuse shown in Table 3, a third of the study participants considered workplace bullying a phenomenon perpetrated by supervisors (i.e., vertical descendent), whereas another third believed that this type of behaviour could also come not only from supervisors, but also from co-workers, establishing the possibility of colleagues bullying (i.e., vertical descendent and horizontal). Finally, the 
TABLE 4

Characteristics of the study variables for the entire sample and subgroups

\begin{tabular}{|c|c|c|c|c|c|c|c|c|c|c|}
\hline \multirow[b]{3}{*}{ Variable } & & & \multicolumn{4}{|c|}{ Service participants } & \multicolumn{4}{|c|}{ Course participants } \\
\hline & \multicolumn{2}{|c|}{$\begin{array}{l}\text { Entire } \\
\text { sample }\end{array}$} & \multicolumn{2}{|c|}{$\begin{array}{l}\text { Costa } \\
\text { Rican }\end{array}$} & \multicolumn{2}{|c|}{ Spanish } & \multicolumn{2}{|c|}{$\begin{array}{l}\text { Costa } \\
\text { Rican }\end{array}$} & \multicolumn{2}{|c|}{ Spanish } \\
\hline & $N$ & $\%$ & $N$ & $\%$ & $N$. & $\%$ & $N$ & $\%$ & $N$ & $\%$ \\
\hline \multicolumn{11}{|l|}{ Type of abuse } \\
\hline Psychological & 197 & 80.1 & 42 & 67.7 & 67 & 89.3 & 41 & 70.7 & 47 & 92.2 \\
\hline Psychological and physical & 49 & 19.9 & 20 & 32.3 & 8 & 10.7 & 17 & 29.3 & 4 & 7.8 \\
\hline \multicolumn{11}{|l|}{ Direction } \\
\hline Vertical descendent & 88 & 35.8 & 30 & 48.4 & 32 & 42.7 & 18 & 31.0 & 8 & 15.7 \\
\hline $\begin{array}{l}\text { Vertical descendent }+ \\
\text { horizontal }\end{array}$ & 77 & 31.3 & 24 & 38.7 & 26 & 34.7 & 15 & 25.9 & 12 & 27.5 \\
\hline All directions & 81 & 32.9 & 8 & 12.9 & 17 & 22.7 & 25 & 43.1 & 31 & 60.8 \\
\hline \multicolumn{11}{|l|}{ Emphasis on categories } \\
\hline 1. Isolation & 24 & 9.8 & 6 & 9.7 & 5 & 6.7 & 4 & 6.9 & 9 & 17.6 \\
\hline $\begin{array}{l}\text { 2. Control/manipulation } \\
\text { of information }\end{array}$ & 1 & 0.4 & 0 & 0.0 & 1 & 1.3 & 0 & 0.0 & 0 & 0.0 \\
\hline $\begin{array}{l}\text { 3. Control/abuse of working } \\
\text { conditions }\end{array}$ & 23 & 9.3 & 4 & 6.5 & 13 & 17.3 & 3 & 5.2 & 3 & 5.9 \\
\hline 4. Emotional abuse & 126 & 51.2 & 31 & 50.0 & 33 & 44.0 & 37 & 63.8 & 25 & 49.0 \\
\hline $\begin{array}{l}\text { 5. Professional discredit or } \\
\text { humiliation }\end{array}$ & 31 & 12.6 & 8 & 12.9 & 9 & 12.0 & 7 & 12.1 & 7 & 13.7 \\
\hline $\begin{array}{l}\text { 6. Devaluation of } \\
\text { professional role }\end{array}$ & 41 & 16.7 & 13 & 21.0 & 14 & 18.7 & 7 & 12.1 & 7 & 13.7 \\
\hline
\end{tabular}

last third of the sample stated in their definitions that workplace bullying could occur between colleagues, bosses, and subordinates alike, indicating the existence of bottom-up workplace bullying as well (i.e., all directions).

When the results between the employees from Central America and Southern Europe were compared, marginal effects for the direction of the abuse were found $(U=6627.00, z=-1.77, p=.08$. However, as shown in Table 4, within these world regions, significant differences according to the direction of the abuse were found between course participants and service participants: Costa Rica, $U=1246.00, \quad z=-3.09, \quad p<.01$; Spain, $U=1095.50, z=-4.32, p<.01$. The Southern European and Central American employees who participated in the courses conceived workplace bullying mainly as a multidirectional process (supervisor, colleagues, and bottom-up bullying), and the ones who did not participate defined it mainly as a top-down process.

Thus, the data showed marginal support for Hypotheses $2 \mathrm{a}$ and $2 \mathrm{~b}$, stating that Central American employees would understand workplace 
bullying more as supervisor bullying and Southern European employees would understand it more as colleague and bottom-up bullying as well. In both subsamples, definitions were similarly distributed, but Southern European employees presented a stronger tendency to understand workplace bullying as an all directions process (supervisor, colleagues, and bottom-up bullying) rather than a top-down process. Finally, data revealed that almost half of the employees' who participated in the courses understood workplace bullying as an all-directions process, whereas almost half of the service employees who did not participate in any course defined it mainly as supervisor bullying.

\section{Direct and indirect aggressive behaviours of workplace bullying}

To investigate differences regarding the emphasis placed on the different workplace bullying categories (see Table 3), we used the Friedman test. It is a nonparametric test based on the analysis of multiple rank orders. It works like the Mann-Whitney $U$ test and is used for the comparison of more than two nonindependent/related groups. It provides a test statistic $Q$, which can be approximated by $\chi^{2}$ if sample size is large $(N>15)$. The Friedman test was applied as normal distribution was not assumed. It showed significant differences between the six categories of abuse used to classify the definitions given by the entire sample (the Costa Rican and the Spanish), $\chi^{2}=236.22$, $p<.01, d f=5$. Emotional abuse was by far the most used category to describe workplace bullying $(51.2 \%$ of the entire sample). In contrast, control and manipulation of information was almost not used $(0.4 \%$ of the entire sample).

However, as indicated in Table 4, no significant differences were found for employees who took the course and those who did not regarding their emphasis on different categories of workplace bullying in either Central America, $U=1683.00, z=-0.67, p=.50$, or Southern Europe, $U=1819.00$, $z=-0.50, p=.62$. Furthermore, as can be seen in Figure 1, when the data was compared between both world regions, no significant differences were found, $U=7021.00, z=-1.04, p=.30$, between the single categories, e.g., isolation: $U=7350.00, \quad z=-0.73, \quad p=.46$; control-abuse of working conditions, $U=7041.00, z=-1.84, p=.07$.

Thus, the results showed that the employees in Central America and Southern Europe conceptualized workplace bullying in a similar way, according to the type of aggressive behaviour used. Specifically, using a nonparametric statistical hypothesis test for the case of two related samples (the Wilcoxon signed-rank test), the data indicated that direct workplace bullying behaviours (such as emotional abuse) were considered more frequently by both the Central American and the Southern European 
$\%$

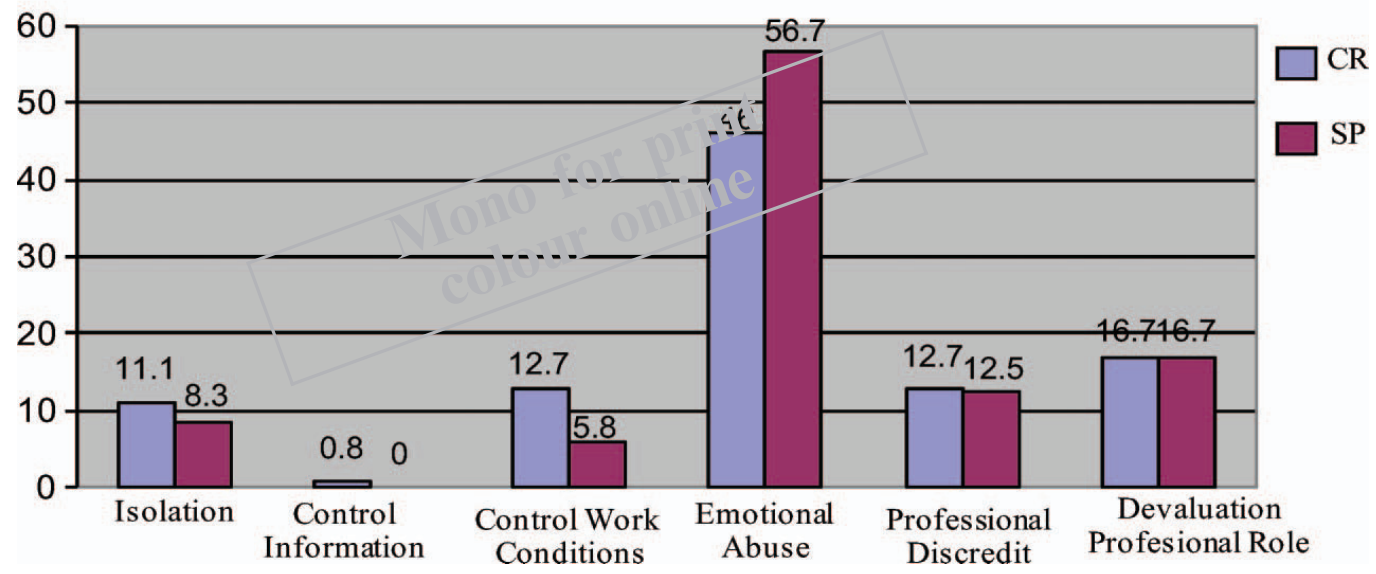

Figure 1. Use of bullying categories for the Central American (CR) and Southern European (SP) sample. Note: No significant differences between Costa Rica (CR) and Spain (SP). To view this figure in colour, please see the online issue of the Journal.

employees, $z=-9.64, p<.01$. Moreover, for both the Southern European and Central American employees, the indirect strategies were conceptually less significant.

Hence, according to Hypothesis 3a, where it was speculated that direct components of workplace bullying would be more relevant in the conceptualization of the phenomenon for the Central American employees than for the Southern European employees, the data did not support the hypothesis, because in Southern Europe direct components were highly relevant, as well. According to Hypothesis 3b, where it was speculated that indirect components of workplace bullying would be more relevant in the conceptualization of the phenomenon for the Southern European employees than for the Central American employees, the data also did not support the hypothesis, because in Southern Europe indirect components were also not very relevant.

\section{DISCUSSION}

The main research question of this study was whether there would be differences in the way workplace bullying is understood by employees in Central America and Southern Europe. According to the results, some differences have been found between both world regions. However, the data also suggests similarities in the conceptualization of workplace bullying across cultures. This is against what was expected, with more similarities than differences being found.

With respect to the first set of hypotheses (1a and $1 \mathrm{~b}$ ), whether workplace bullying is a physical or a psychological phenomenon, the results showed that one-third of the employees from Central America said that physical 


\section{ESCARTÍN ET AL.}

strategies together with psychological strategies are part of their workplace bullying definitions. In contrast, most of the Southern European employees defined workplace bullying as a psychological phenomenon. It could be argued that in Southern Europe more subtle strategies could be used in order to lower the risk of being identified and/or punished, which is coherent with the effect-danger ratio theory of aggression (Bjorkqvist et al., 1994). In contrast, in Central America, as noted by Wilkinson (1998, cited in Bond, 2004), physical behaviours could be seen as a way to get respect from others. Also, such differences could be explained by the influence of the North American research tradition on workplace violence and hostile workplace behaviours, which is defined also by physical behaviours (Keashly \& Jagatic, 2003; Neuman \& Baron, 2005). In addition to this, the fact that such a phenomenon has received public and scientific attention recently in Central America could facilitate an easier recognition of overt aggression towards employees (Forrest, Eatough, \& Shevlin, 2005). This is opposed to covert aggression, which is normally more difficult to recognize, although not necessarily less damaging than other types of abuse. In comparison to Southern European countries, recent interest and commitment to preventing sexual harassment (Cortina, 2004) in some Central American countries could have led to an overestimation of the physical component. Nevertheless, although significant differences occurred, some similarities between both subsamples were found as well. This could be partially explained by an extrapolation of the influence from European on American research, which may have taken place since the late 1980s, as it is noted by Keashly and Harvey (2006, p. 107): “Leymann's (1990) work on mobbing in the workplace fuelled an incredible burst of empirical research in the European Community that was and continues to be influential in thinking about and examining workplace emotional abuse in the United States and Canada." Thus, such European research could have influenced Central America, as well.

With respect to the second set of hypotheses ( $2 \mathrm{a}$ and $2 \mathrm{~b}$ ), whether workplace bullying is a hierarchical or a horizontal phenomenon, workplace bullying has been understood in both world regions as supervisors bullying employees, which is coherent with previous research about abusive supervision (e.g., Ashforth, 1997; Tepper, 2000). However, the course participants defined it not only as supervisor bullying, but also as colleagues and subordinates bullying. It has been argued that power distance is a crucial variable (Liefooghe \& Mackenzie-Davey, 2001) and that strong hierarchical relations make workplace bullying behaviours more likely to arise. Thus, according to the definition of power distance provided by House et al. (2004, p. 12), it could be argued that in both Southern Europe and Central America, where there exists high levels of male domination, work relations facilitate some top-down behaviours that could be commonly 
understood as workplace bullying. This is in line with other studies on this topic (Aryee, Sun, Xiong, \& Debrah, 2007; Skogstad, Einarsen, Torsheim, Schanke, \& Hetland, 2007) and the so-called "macho culture" (Tedeschi \& Bond, 2001). The difference between the course participants and the service participants is likely to be explained by their motivation and interest in the topic, which could have led them to be better informed about the phenomenon of workplace bullying. These interested participants whose motivation or interest may have been a result of witnessing workplace bullying developed a more differentiated picture of bullying independently of the work region they were coming from.

With respect to the third set of hypotheses ( $3 a$ and $3 b$ ), the entire sample emphasized the direct aggressive behaviours, specifically the emotional aspects, in their understanding of workplace bullying. Scientific literature has offered several definitions that have also stressed such an emotional dimension through the term "emotional abuse" (Einarsen, 1999), a concept introduced by Keashly, Trott, and MacLean (1994) as a significant component of the workers' experience. In addition to this, the indirect aggressive behaviours were used less to define workplace bullying. Aspects of workplace bullying such as social isolation, obstructionism, or misuse of information were generally not used by the employees in their definitions. Furthermore, these results add weight to the distinction provided by several authors, between person-oriented acts (acts directed at the person and his or her personality and behaviours, e.g., being ignored, ridiculed, or shouted at) and work-oriented acts (i.e., indirect aggressive acts directed at the person's work tasks and work role, e.g., being given tasks with impossible targets or deadlines; e.g., Notelaers, Einarsen, de Witte, \& Vermunt, 2006). Personoriented acts best fit with the "emotional abuse" category, whereas most of the other categories fit with the work-oriented acts. In the task of defining workplace bullying, attacks against the person and strategies that focus on direct abusive action have more relevance than those aimed at influencing the working environment. This is consistent with various studies (e.g., Hansen et al., 2006) that have analysed how the aggressors or actors in the workplace bullying process tend to use those abusive strategies that attack the fundamental aspects of the self, thus gradually bringing about changes in the perceptions and beliefs of their victims. However, it is contrary to other studies that have found indirect negative acts to be most frequently reported (i.e., Kelloway et al., 2006). Nevertheless, the fact that the direct negative acts were far more considered when defining workplace bullying is explained by Keashly (1998), who pointed out that the preponderance of certain acts may be because targets and witnesses can identify the action and its harmfulness. And conversely, Keashly (2001) pointed out as well that certain subtle acts are more difficult to describe being more complex to discern for targets and witnesses. 


\section{ESCARTÍN ET AL.}

To sum up, this is one of the first studies that has tried to analyse how workplace bullying can vary across cultures, reflecting not only the differences but also the existing similarities. Hence, these results highlight the nature and the phenomenon per se, which have some "core aspects" 905 shared by different working populations in different world regions, such as Central America and Southern Europe. These small differences could be caused by the globalization processes, which is leading to a worldwide cultural convergence (Dorfman \& House, 2004), where "the nature of the industry influences organizational culture through the constraints it places 910 on the behaviour of all persons in the organization" (Dickson, Aditya, \& Chhokar, 2000, p. 454).

From a practical point of view, the fact that the workers' understanding of workplace bullying does not differ substantially among these world regions has some positive implications for the development and 915 implementation of different strategies for dealing effectively with this phenomenon (Agervold, 2007; Hoel \& Beale, 2006; Zapf \& Gross, 2001) in parts of the world where little research exists such as Central America. These findings should contribute to the development of intervention strategies in which the emphasis lies above all on prevention processes, reflecting how a detailed understanding of the abusive behaviours is an essential step in establishing a preventive action plan. Likewise, information campaigns and specific training programmes could facilitate the emergence of shared meanings among the employees of an organization, with the objective of marking acceptable and unacceptable behaviours, and leading to the development and implementation of codes of conduct in such organizations.

Some of the limitations of the study should be stated. For example, although the use of a convenience sample could have provoked a selfselection bias, the insignificant differences between subsamples stressed that it did not drastically affect the study. Particularly, the potential bias related to the different way to approach the sample, which could be explained by their motivation and interest in the topic, should be further addressed in future research. Furthermore, the qualitative approach of this study does not exclude that researchers may have been biased towards their research hypotheses when analysing the data. However, the high interrater agreement suggests that such a bias may not be too strong. Although possible differences in the media in both world areas could have influenced the data, the study of Lewis (2001) suggests that the conceptualization of bullying is only marginally influenced by such sources.

940 Summing up, this is one of the few studies to look at workplace bullying from a cross-cultural perspective; the challenge ahead is very inspiring and lies in conducting research within a wider set of world regions. This study adds value to the field, in the sense that it offers a set of results that will 
hopefully stimulate research on the cross-cultural similarities and differences of workplace bullying, which might provide a scientific basis to protect and promote occupational health worldwide.

\section{REFERENCES}

Adams, A. (1992). Bullying at work: How to confront and overcome it. London: Virago.

Agervold, M. (2007). Bullying at work: A discussion of definitions and prevalence, based on an empirical study. Scandinavian Journal of Psychology, 48, 161-172.

Anderson, C., \& Bushman, B. (2002). Human aggression. Annual Review of Psychology, 53, 27-51.

Andolsek, D., \& Stebe, J. (2004). Multinational perspectives on work values and commitment. International Journal of Cross-cultural Management, 4, 181-209.

Aquino, K., \& Thau, S. (2009). Workplace victimization: Aggression from the target's perspective. Annual Review of Psychology, 60, 717-741.

Arriagada, I., \& Godoy, L. (1990). Seguridad ciudadana y violencia en América Latina: Diagnóstico y políticas en los años noventa [Citizen security and violence in Latin America: Diagnosis and politics in the 1990s] (Social Policy Series No. 32). Santiago, Chile: Economic Commission for Latin America and the Caribbean. Retrieved 19 July 2008, from www.eclac.org/publicaciones/xml/7/4657/lc11179e.pdf

Aryee, S., Sun, L., Xiong, Z., \& Debrah, Y. (2007). Antecedents and outcomes of abusive supervision: Test of a trickle-down model. Journal of Applied Psychology, 92, 191-201.

Ashforth, B. E. (1997). Petty tyranny in organizations: A preliminary examination of antecedents and consequences. Canadian Journal of Administrative Sciences, 14, 126-140.

Azfar, O., \& Gurgur, T. (2004). Crime, crime reporting and governance (Mimeo). College Park, MD: IRIS University of Maryland.

Barling, J., Dupré, K. E., \& Kelloway, E. K. (2009). Predicting workplace aggression and violence. Annual Review of Psychology, 60, 671-692.

Baron, R. A., \& Neuman, J. H. (1996). Workplace violence and workplace aggression: Evidence on their relative frequency and potential causes. Aggressive Behaviour, 22, 161173.

Bjorkqvist, K., Osterman, K., \& Hjelt-Back, M. (1994). Aggression among university employees. Aggressive Behaviour, 20, 173-184.

Bond, M. (2004). Culture and aggression: From context to coercion. Personality and Social Psychology Review, 8(1), 62-78.

Branch, S. (2008). You say tomatoe and I say tomato: Can we differentiate between workplace bullying and other counterproductive behaviours? International Journal of Organisational Behaviour, 13(2), 4-17.

Budd, J. W., Arvey, R. D., \& Lawless, P. (1996). Correlates and consequences of workplace violence. Journal of Occupational Health Psychology, 1, 197-210.

Buss, A. (1961). The psychology of aggression. New YorkA: Wiley.

Campos, P., Abarca, C., \& Prado, G. (2005). Acoso moral y acoso sexual en el lugar de trabajo [Moral and sexual harassment at the work place]. Medicina legal de Costa Rica, 22(2), 17-54.

CID Gallup. (2005). Public opinion survey 58. San José, Costa Rica: Author. Retrieved 19 June 2008, from http://www.cidgallup.com/Documentos/OP58SALe.pdf

Cortina, L. M. (2004). Hispanic perspectives on sexual harassment and social support. Personality and Social Psychology Bulletin, 30(5), 570-584. 


\section{ESCARTÍN ET AL.}

Cortina, L. M., Magley, V. J., Williams, J. H., \& Langhout, R. D. (2001). Incivility in the workplace: Incidence and impact. Journal of Occupational Health Psychology, 6, 64-80.

Cruz, J. (Ed.). (2006). Maras y pandillas en Centroamérica. Las respuestas de la sociedad civil organizada [Maras and gangs in Central America: The answers from the organized civil society] San Salvador, IV.

Davenport, N., Schwartz, R. D., \& Elliott, G. P. (1999). Mobbing: Emotional abuse in the workplace. CSP: USA.

Dickson, M., Aditya, R., \& Chhokar, J. (2000). Definition and interpretation in cross-cultural organizational culture research: Some pointers from the GLOBE research program. In N. M. Ashkanasy, C. P. M. Wilderom, \& M. F. Peterson (Eds.), Handbook of organizational culture and climate (pp. 447-464). Thousand Oaks, CA: Sage.

Di Martino, V., Hoel, H., \& Cooper, C. L. (2003). Prevention of violence and harassment in the workplace. Dublin, Ireland: European Foundation for the Improvement of Living and Working Conditions.

Dollard, M. F., LaMontagne, A. D., Shaw, A., Blewett, V., Caulfield, N., Jordan, J., et al. (2006). Job stress: Causes, impact and solutions in the health and community services sector. A literature review. In V. Blewett, A. Shaw, A. D. LaMontagne, \& M. F. Dollard (Eds.), Job stress: Causes, impact and solutions in the health and community services sector. Sidnez; WorkCover NSW. Retrieved 18 June 2008, from http://www.workcover.nsw. gov.au/Publications/General/Research/job-stress_causes_impact_interventions_in_health_ community_sector.htm

Dorfman, P., \& House, R. (2004). Cultural influences on organizational leadership: Literature review, theoretical rationale, and GLOBE project goals. In R. J. House, P. J. Hanges, M. Javidan, P. Dorfman, \& V. Gupta (Eds.), Leadership, culture and organizations: The GLOBE study of 62 societies (pp. 49-71). Thousand Oaks, CA: Sage.

Duffy, M. K., Ganster, D. C., \& Pagon, M. (2002). Social undermining in the workplace. Academy of Management Journal, 45, 331-352.

Einarsen, S. (1999). The nature and causes of bullying at work. International Journal of Manpower, 20, 16-27.

Einarsen, S. (2000). Harassment and bullying at work: A review of the Scandinavian approach. Aggression and Violent Behaviour: A Review Journal, 4, 371-401.

Einarsen, S., Hoel, H., Zapf, D., \& Cooper, C. L. (2003). The concept of bullying at work: The European tradition. In S. Einarsen, H. Hoel, D. Zapf, \& C. L. Cooper (Eds.), Bullying and emotional abuse in the workplace: International perspectives in research and practice (pp. 3-30). London \& New York: Taylor \& Francis.

ERIC, IDESO, IDIES, \& IUDOP. (Eds.). (2004). Maras y pandillas en Centroamérica, 3 [Maras and gangs in Central America, Vol. 3] San Salvador, El Salvador: Editors.

Escartín, J., Arrieta, C., \& Rodríguez-Carballeira, A. (2009). Mobbing o acoso laboral: Revisión de los principales aspectos teórico-metodológicos que dificultan su estudio [Mobbing or workplace harassment: Revision of the main theoretic-methodological aspects that make its study difficult]. Actualidades en Psicología, 23(110), 1-25.

Escartín, J., Rodríguez-Carballeira, A., Porrúa, C., \& Martín-Peña, J. (2008). Estudio y análisis sobre cómo perciben el mobbing los trabajadores [Study and analysis of the way mobbing is perceived by workers]. Revista de Psicología Social, 23(2), 203-211.

Escartín, J., Rodríguez-Carballeira, A., Zapf, D., Porrúa, C., \& Martín-Peña, J. (2009). Perceived severity of various bullying behaviours at work and the relevance of exposure to bullying. Work and Stress, 23(3), 191-205.

Forrest, S., Eatough, V., \& Shevlin, M. (2005). Measuring adult indirect aggression: The development and psychometric assessment of the indirect aggression scales. Aggressive Behaviour, 31, 84-97. 
Gelfand, M., Erez, M., \& Aycan, Z. (2007). Cross-cultural organizational behaviour. Annual Review of Psychology, 58, 479-514.

Hansen, A. M., Hogh, A., Persson, R., Karlson, B., Garde, A. H., \& Orbaek, P. (2006). Bullying at work, health outcomes, and physiological stress response. Journal of Psychosomatic Research, 60(1), 63-72.

Harvey, M., Treadway, D., Heames, J., \& Duke, A. (2009). Bullying in the 21st century global organization: An ethical perspective. Journal of Business Ethics, 85, 27-40.

Hirigoyen, M. (2001). El acoso moral en el trabajo [Moral harassment in the workplace]. Barcelona, Spain: Paidós.

Hodson, R., Roscigno, V., \& Lopez, S. (2006). Chaos and the abuse of power. Workplace bullying in organizational and interactional context. Work and Occupations, 33, 382-416.

Hoel, H., \& Beale, D. (2006). Workplace bullying, psychological perspectives and industrial relations: Towards a contextualised and interdisciplinary approach. British Journal of Industrial Relations, 44(2), 239-262.

Hoel, H., \& Cooper, C. L. (2000). Destructive conflict and bullying at work. Unpublished report, University of Manchester, Institute of Science and Technology.

Hoel, H., Faragher, B., \& Cooper, C. L. (2004). Bullying is detrimental to health, but all bullying behaviours are not necessarily equally damaging. British Journal of Guidance and Counselling, 32(3), 367-387.

Hoel, H., \& Salin, D. (2003). Organisational antecedents of workplace bullying. In S. Einarsen, H. Hoel, D. Zapf, \& C. L. Cooper (Eds.), Bullying and emotional abuse in the workplace: International perspectives in research and practice (pp. 203-218). London: Taylor \& Francis.

Hoel, H., Sparks, K., \& Cooper, C. L. (2001). The cost of violence/stress at work and the benefits of a violence/stress-free working environment. Geneva, Switzerland: International Labour Organization.

Hofstede, G. (1980). Culture's consequences. New York: Sage.

Hofstede, G. (1994). Cultures and organizations, software of the mind: Intercultural cooperation and its importance for survival. London: McGraw-Hill.

House, R., Hanges, P., Javidan, M., Dorfman, P., \& Gupta, V. (Eds.). (2004). Culture, leadership and organizations: The GLOBE study of 62 societiesThousand Oaks, CA: Sage.

Huhn, S., Oettler, A., \& Peetz, P. (2006a). Exploding crime? Topic management in Central American newspapers (GIGA Working Paper No. 33). Hamburg, Germany: German Institute of Global and Area Studies. Retrieved from www.giga-hamburg.de/workingpapers

Huhn, S., Oettler, A., \& Peetz, P. (2006b). Construyendo inseguridades: aproximaciones a la violencia en Centroamérica desde el análisis del discurso [Building insecurities: Approaches to the violence in Central America from the discourse analysis] (GIGA Working Paper No. 34). Hamburg, Germany: German Institute of Global and Area Studies. Retrieved from www.giga-hamburg.de/workingpapers

Ireland, J. (2006). Bullying among mentally-ill patients detained in a high-secure hospital: An exploratory study of the perceptions of staff and patients into how bullying is defined. Aggressive Behaviour, 32, 451-463.

Keashly, L. (1998). Emotional abuse in the workplace: Conceptual and empirical issues. Journal of Emotional Abuse, 1, 85-117.

Keashly, L. (2001). Interpersonal and systemic aspects of emotional abuse at work: The target's perspective. Violence and Victims, 16(3), 233-268.

Keashly, L., \& Harvey, S. (2006). Workplace emotional abuse. In E. K. Kelloway, J. Barling, \& J. J. Hurrell, Jr. (Eds.), Handbook of workplace violence (pp. 95-120). Thousand Oaks, CA: Sage.

Keashly, L., \& Jagatic, K. (2003). By any other name: American perspectives on workplace bullying. In S. Einarsen, H. Hoel, D. Zapf, \& C. L. Cooper (Eds.), Bullying and emotional abuse in the workplace: International perspectives in research and practice (pp. 31-61). London: Taylor \& Francis. 


\section{ESCARTÍN ET AL.}

Keashly, L., Trott, V., \& MacLean, L. M. (1994). Abusive behaviour in the workplace: A preliminary investigation. Violence and Victims, 9(4), 341-357.

Kelloway, E. K., Barling, J., \& Hurrell, J. J., Jr. (Eds.). (2006). Handbook of workplace violence. Thousand Oaks, CA: Sage.

Lam, S., Hui, C., \& Law, K. (1999). Organizational citizenship behaviour: Comparing perspectives of supervisor and subordinates across four international samples. Journal of Applied Psychology, 84, 594-601.

Latourette, K. (1965). Christianity through the ages. New York: Harper \& Row.

LaVan, H., \& Marty, M. (2008). Bullying in the US workplace: Normative and process-oriented ethical approaches. Journal of Business Ethics, 83, 147-165.

Lewis, D. (2001). Perceptions of bullying in organizations. International Journal of Management and Decision Making, 2(1), 48-63.

Lewis, D., \& Rayner, C. (2003). Workplace bullying and HRM: A wolf in sheep's clothing. In S. Einarsen, H. Hoel, D. Zapf, \& C. L. Cooper (Eds.), Bullying and emotional abuse in the workplace: International perspectives in research and practice (pp. 370-382). London: Taylor \& Francis.

Leymann, H. (1990). Mobbing and psychological terror at workplaces. Violence and Victims, 5, $119-126$.

Leymann, H. (1996). The content and development of mobbing at work. European Journal of Work and Organizational Psychology, 5(2), 165-184.

Liefooghe, A., \& Mackenzie-Davey, K. (2001). Accounts of workplace bullying: The role of the organization. European Journal of Work and Organizational Psychology, 10(4), 375-392.

Liefooghe, A., \& MacKenzie-Davey, K. (2003). Explaining bullying at work: Why should we listen to employee accounts? In S. Einarsen, H. Hoel, D. Zapf, \& C. L. Cooper (Eds.), Bullying and emotional abuse in the workplace: International perspectives in research and practice (pp. 103-126). London: Taylor \& Francis.

Lutgen-Sandvik, P. (2008). Intensive remedial identity work: Responses to workplace bullying trauma and stigmatization. Organization, 15(1), 97-119.

Lutgen-Sandvik, P., Tracy, S., \& Alberts, J. (2007). Burned by bullying in the American workplace: Prevalence, perception, degree and impact. Journal of Management Studies, 44(6), 837-862.

Matthiesen, S. B., \& Einarsen, S. (2001). MMPI-2 configurations among victims of bullying at work. European Journal of Work and Organizational Psychology, 32, 335-356.

Mayhew, C., \& Chappell, D. (2007). Workplace violence: An overview of patterns of risk and the emotional/stress consequences on targets. International Journal of Law and Psychiatry, $30,327-339$.

Moayed, F., Daraiseh, N., Shell, R., \& Salem, S. (2006). Workplace bullying: A systematic review of risk factors and outcomes. Theoretical Issues in Ergonomics Science, 7(3), 311-327.

Moreno-Jiménez, B., Rodríguez-Muñoz, A., Salin, D., \& Benadero, M. E. (2008). Workplace bullying in Southern Europe: Prevalence, forms and risk groups in a Spanish sample. International Journal of Organisational Behaviour, 13(2), 95-109.

(5) perceptions from Colombia and Guatemala. New York.

Neuman, J. H., \& Baron, R. A. (2005). Aggression in the workplace: A social-psychological perspective. In S. Fox \& P. E. Spector (Eds.), Counterproductive work behaviour (pp. 13-40). Washington, DC: American Psychological Association.

(6) Newman, D. (2008). Sociology: Exploring the architecture of everyday life (7th ed.). Sage.

Nielsen, M., Skogstad, A., Matthiesen, S., Glasø, L., Aasland, M., Notelaers, G., \& Einarsen, S. (2009). Prevalence of workplace bullying in Norway: Comparisons across time and estimation methods. European Journal of Work and Organizational Psychology, 18(1), $81-101$. 
Notelaers, G., Einarsen, S., de Witte, H., \& Vermunt, J. K. (2006). Measuring exposure to bullying at work: The validity and advantages of the latent class cluster approach. Work and Stress, 20, 288-301.

Oettler, A. (2007). Discourses on violence in Costa Rica, El Salvador and Nicaragua: National patterns of attention and cross-border discursive nodes (GIGA Working Paper No. 65). Hamburg, Germany: German Institute of Global and Area Studies. Retrieved from www.giga-hamburg.de/workingpapers

PAHO. (1998). Health in the Americas. Washington, DC: Author.

Pando, M., Aranda, C., Franco, S., \& Torres, T. (2008, November). Violencia psicológica y mobbing en Costa Rica [Psychological Violence and Mobbing in Costa Rica]. Paper presented at the eighth European Academy of Occupational Health Psychology, University of Valencia, Spain.

Peterson, M., \& Smith, P. (1997). Does national culture or ambient temperature explain crossnational differences in role stress? No sweat! Academy of Management Journal, 40, 930-946.

PREAL. (2007). A lot to do: A report card on education in Central America and the Dominican Republic. Washington, DC: Author.

Rayner, C., \& Cooper, C. L. (2006). Workplace bullying. In E. K. Kelloway, J. Barling, \& J. J. Hurrell, Jr. (Eds.), Handbook of workplace violence (pp. 121-146). Thousand Oaks, CA: Sage.

Rayner, C., \& Keashly, L. (2005). Bullying at work: A perspective from Britain and North America. In S. Fox \& P. E. Spector (Eds.), Counterproductive work behaviour (pp. 271-296). Washington, DC: American Psychological Association.

Rico, J. (2006). (In) seguridad ciudadana en Costa Rica: Balance de la situación [Citizen (in) security in Costa Rica]. San José, Costa Rica: Programa de las Naciones Unidas para el desarrollo (PNUD).

Rodríguez-Carballeira, A., Almendros, C., Escartín, J., Porrúa, C., Martín-Peña, J., Javaloy, F., \& Carrobles, J. A. (2005). Un estudio comparativo de las estrategias de abuso psicológico: en pareja, en el lugar de trabajo y en grupos manipulativos [A comparative study of psychological abuse strategies in different fields: Couples, workplace and groups employing psychological manipulation]. Anuario de Psicología, 36(3), 299-314.

Rodríguez-Carballeira, A., Escartín, J., Visauta, B., Porrúa, C., \& Martín-Peña, J. (in press). Categorization and hierarchy of workplace bullying strategies: A Delphi survey.

Romero-Pérez, J. (2006). Mobbing laboral: Acoso moral, psicológico [Mobbing: Moral and psychological harassment]. Revista de Ciencias Jurídicas, 111, 131-162.

Rosenn, K. (1988). A comparison of Latin American and North American legal traditions. In L. Tavis (Ed.), Multinational managers and host government interactions (pp. 127-152). South Bend, IN: University of Notre Dame Press.

Saam, N. J. (in press). Interventions in workplace bullying: A multilevel approach. European Journal of Work and Organizational Psychology.

Salas, G. (2005). El nuevo dilema del derecho laboral: acoso psicológico y moral en el trabajo [The new labour law dilemma: Workplace and moral harassment]. Revista de Medicina Legal en Costa Rica, 22(2), 55-74.

Saunders, P., Huynh, A., \& Goodman-Delahunty, J. (2007). Defining workplace bullying behaviour professional lay definitions of workplace bullying. Law and Psychiatry, 30, 340-354.

Schaffter, B., \& Riordan, C. (2003). A review of cross-cultural methodologies for organizational research: A best-practices approach. Organizational Research Methods, 6(2), 169-215.

Skogstad, A., Einarsen, S., Torsheim, T., Schanke, M., \& Hetland, H. (2007). The destructiveness of laissez-faire leadership behaviour. Journal of Occupational Health Psychology, 12(1), 80-92.

Smith, P., Cowie, H., Olafsson, R., \& Liefooghe, A. (2002). Definitions of bullying: A comparison of terms used, and age and gender differences, in a fourteen-country international comparison. Child Development, 73(4), 1119-1133. 


\section{ESCARTÍN ET AL.}

Strandmark, M., \& Hallberg, L. (2007). The origin of workplace bullying: Experience from the perspective of bully victims in the public service sector. Journal of Nursing Management, 15, 332-341.

Tedeschi, J., \& Bond, M. (2001). Aversive behaviour and aggression in cross-cultural perspectives. In R. Kowalski (Ed.), Behaving badly: Aversive behaviours in interpersonal relationships (pp. 257-293). Washington, DC: American Psychological Association.

Tepper, B. J. (2000). Consequences of abusive supervision. Academy of Management Journal, 43(2), 178-190.

Topa, G., Depolo, M., \& Morales, F. (2007). Acoso laboral: meta-análisis y modelo integrador de sus antecedentes y consecuencias [(Workplace harassment: Meta-analysis and integrative model of antecedents and consequences]. Psicothema, 19(1), 88-94.

Transparency International. (2008). Transparency International (TI) report on the corruption perceptions. Retrieved 10 March 2009, from www.icgg.org/corrpution.cpi_2008.html

Triandis, H. (1992). Cross-cultural research in social psychology. In D. Granberg \& G. Sarup (Eds.), Social judgment and intergroup relationships: Essays in honor of Muzafer Sherif. New York: Springer-Verlag.

Triandis, H. (2004). The many dimensions of culture. Academy of Management Executive, 18, $88-93$.

Tsui, A., Nifadkar, S., \& Yi, A. (2007). Cross-national, cross-cultural organizational behaviour research: Advances, gaps, and recommendations. Journal of Management, 33(3), 426-478.

UNESCO. (2004). (Various reports.) Montreal, Canada: Institute for Statistics. Retrieved from www.unesco.org

Vartia, M. (2001). Consequences of workplace bullying with respect to well-being of its targets and the observers of bullying. Scandinavian Journal of Work Environment and Health, 27, 63-69.

Verweij, J., \& Nauta R. (1997). Secularization as an economic and cultural phenomenon: A cross-national analysis. Journal for the Scientific Study of Religion, 36, 309-324.

Webster's new encyclopedic dictionary. (1995). (Rev. ed., 1st printing). New York: Black Dog and Leventhal Publishers.

(11) threats at work. MD: Government Institutes.

World Economic Forum. (2008). The global competitiveness report 2008-2009. Geneva, Switzerland: Author.

Yamada, D. (2004). Crafting a legislative response to workplace bullying. Employee Rights and Employment Policy Journal, 8, 475-521.

Zapf, D., \& Einarsen, S. (2005). Mobbing at work: Escalated conflicts. In S. Fox \& P. E. Spector (Eds.), Counterproductive work behaviour (pp. 237-270). Washington, DC: American Psychological Association.

Zapf, D., Escartín, J., Einarsen, S., Hoel, H., \& Vartia, M. (2010). Empirical findings on the prevalence rate and risk groups of bullying in the workplace. In S. Einarsen, H. Hoel, D. Zapf, \& C. L. Cooper (Eds.), Workplace bullying: Development in theory, research and practice. London: Taylor \& Francis.

Zapf, D., \& Gross, C. (2001). Conflict escalation and coping with workplace bullying: A replication and extension. European Journal of Work and Organizational Psychology, 10(4), $497-522$.

Original manuscript received September 2008

Revised manuscript received September 2009

First published online month/year 